\title{
Comparison of ormeloxifen and mifepristone in management of leiomyoma uterus
}

\author{
Madhulika Singh $^{1 *}$, Amrita Chourasia ${ }^{2}$, Shalini Singh $^{3}$, Nidhi Sachan ${ }^{4}$ \\ ${ }^{1}$ Junior Resident, ${ }^{2}$ Associate Professor, ${ }^{3,4}$ Lecturer, ${ }^{1-4}$ Dept. of Obstetrics and Gynaecolog, ${ }^{1-4}$ Moti Lal Nehru Medical College, Allahabad, \\ Uttar Pradesh, India \\ *Corresponding Author: Madhulika Singh \\ Email: drmadhulikasingh86@gmail.com
}

Received: $28^{\text {th }}$ July, 2018

Accepted: $18^{\text {th }}$ September, 2018

\begin{abstract}
Aims and Objectives: To compare the effect of mifepristone and ormeloxifen on symptomatology, size and vascularity of fibroid and also to compare the compliance and side effects of both these drugs.

Materials and Methods: This study was conducted in the department of obstetrics and gynecology at Swaroop Rani Nehru hospital, Allahabad and Kamla Nehru memorial hospital, Allahabad over a period of one year between 2016-2017 in 90 fibroid patients who gave consent for the study. Depending on their choice they were randomly divided into 2 groups. Group A included 44 fibroid patients who were given mifepristone and Group B included 46 fibroid patients were given ormeloxifen. Assessment of heavy menstrual bleeding by pictorial blood loss assessment chart, dysmenorrhea and dyspareunia by visual analogue scale, estimation of hemoglobin and repeat imaging to assess size, number, endometrial thickness, Doppler velocimetry of fibroid was done and all variables were compared in relation to pretreatment and post-treatment parameters by using chi square test.

Results: $97.7 \%$ patients in group A and $95.6 \%$ patients in group B were compliant towards treatment. A significant reduction in HMB (group A-51.16\% to $18.6 \%$ \$ group B-45.45\% to 20.45\%), mean pbac score(group A-246.6 to 65.2;p<0.0001 \$ group B-242.4 to $66.5 ; \mathrm{p}<0.0001$ ) and mean VAS(group A-7.5 \pm 2.6 to 2.0 $\pm 0.6 \$$ group B-7.0 \pm 2.1 to 1.80 .3 ) was found with significant rise in Hb level (grp A-9.6 1.5 to $12.41 .2 ; \mathrm{p}<0.001$ grp B-10.0 1.8 to $12.61 .6 ; \mathrm{p}<0.001$ )during 6 months follow up. On USG a significant reduction in size of fibroid was found with mifepristone $(\mathrm{p}<0.0001)$ as compared to ormeloxifen $(\mathrm{p}<0.624)$ while significant reduction in vascularity was noted with both of them(Group A-p $<0.001$, Group B-p $<0.001$ ). Significant endometrial hyperplasia noted with mifepristone( $<<0.0001)$ while significant reduction with ormeloxifen $(\mathrm{p}<0.0001)$

Conclusion: Mifepristone and ormeloxifen were equally effective for symptomatic relief in fibroid patients. Myoma size was significantly reduced by mifepristone only, with notable endometrial hyperplasia whereas ormeloxifen causes significant reduction in endometrial thickness. No major side effects observed with any of them.
\end{abstract}

Keywords: Mifepristone, Ormeloxifen, Leiomyoma, SERM, PBAC score.

\section{Introduction}

Uterine fibroid is a common concern due to associated heavy menstrual bleeding and anemia negatively affecting women's life. The prevalence of uterine fibroid in India is upto $20-30 \%$ in reproductive females ${ }^{1}$ and $10-20 \%$ of infertility is attributed to uterine fibroid ${ }^{2,3}$ thus it becomes a major socioeconomic health burden to the society. Though surgical treatment still remains the mainstay of the treatment, medical methods had evolved over the years with the advent of many effective oral drugs. Growing evidences indicate that progesterone and estrogen receptor play key role in uterine leiomyoma development and growth. ${ }^{4}$ Progesterone causes suppressed apoptosis and stimulates proliferation of the leiomyomatous smooth muscles. ${ }^{5-7}$ Whereas estrogen indirectly stimulates leiomyoma growth by up-regulating the progesterone receptors. Progesterone and estrogens also affect leiomyomatous growth by up regulation of EGF (epidermal growth factor) which increases estrogen and hence progesterone receptors ${ }^{12}$ and VEGF which increases fibroid vascularity. ${ }^{14,15}$ An antiprogestogenic and antiestrogenic medication will antagonize progesterone and estrogenic action on fibroid and will help in reducing its size. Over the years the continued search had led to the development of such magic bullet fulfilling the maximum criteria of "Ideal Tablet" that can be given orally in least frequent dosing with minimal side effects has evolved antiprogesterone mifepristone and antiestrogen ormeloxifene.

\section{Material and Method \\ Type of Study \\ Interventional}

\section{Place of Study}

Department of Obstetric and Gynaecology at Swaroop Rani Nehru hospital, Allahabad and Kamala Nehru Memorial hospital, Allahabad over a period of one year; 2016-2017.

\section{Sampling Methods}

Incidental sampling

\section{Inclusion Criteria}

All symptomatic or asymptomatic patients of uterine leiomyoma aged 20-50 yrs. Asympytomatic patients with incidental diagnosis of fibroid uterus in imaging were enrolled in the study with the purpose to see the effect of these drugs on size and vascularity of uterine fibroid 


\section{Exclusion Criteria}

Big fibroids (size more than $15 \mathrm{~cm}$ by ultrasonography), uterine size more than 20 weeks, coexisting adenomyosis, endometriosis and adnexal masses, malignancies of uterus/cervix/ovary/vagina/endometrial hyperplasia with atypia,hormonal medication within 3 months, medical diseases like - liver dysfunction, heart disease, migraine, stroke, renal disease, hypo/hyperthyroidism, platelet disorders or coagulopathy, hypersensitivity to the drug and very severe anaemia $<6 \mathrm{gm} / \mathrm{dl}$,non consenting patients.

\section{Sample Collection}

90 patients with fibroid uterus were interrogated and examined thoroughly and then were divided into two arbitrary groups (A \& B) on the basis of their choice of drug; mifepristone or ormeloxifene.

\section{Intervention}

Group A included 44 women who took mifepristone $10 \mathrm{mg}$ once daily for six months.

Group B included 46 women who took ormeloxifen $60 \mathrm{mg}$ twice weekly for six months.

\section{Follow ups}

The follow-ups were done at 3 and 6 monthly intervals. The parameters assessed were amount of menstrual blood loss (Pictorial blood loss assessment chart; abnormal PBAC score $\geq 100$ ), dysmenorrhea (Visual analogue scale; abnormal scale >3), pressure symptom, ultrasonographic assessements of size \& number of fibroid, endometrial thickness, uterine vascularity through Doppler velocimetry and adverse effect.

\section{Statistical Analysis}

The statistical significances were measured by calculating $\mathrm{P}$ value $(\mathrm{P}$ value $<0.05)$

\section{Results}

Table 1: Mean age of women in group A \& Group B were $40.8 \pm 6.8$ and $41.2 \pm 7$ respectively. In both the groups maximum numbers of patients were from urban background; $76.7 \%$ and $90.9 \%$, belonged to middle class; $65.1 \%$ and $61.4 \%$, were married; $88.4 \%$ and $95.5 \%$ with parity three; $32.55 \%$ and $36.36 \%$ in group A and group B respectively.

Table 2: Heavy menstrual bleeding without dysmenorrhea was the most common symptom; $50 \%$ followed by HMB with dysmenorrhoea;27.3\% followed by pressure symptoms;3.5\%.

In Group A at $3 \& 6$ months of followup reduction in HMB without dysmenorrhea were statistically significant; $23.3 \%(\mathrm{p}<0.005) \& 6.9 \%(\mathrm{p}<0.001)$ and in group B $25 \%(0.005) \& 6.8 \%(\mathrm{p}<0.001)$ whereas HMB with dysmenorrhea had significant improvement only at 3 month followup;9.3\% $(p<0.005)$ in group A and 6.8\% $(p<0.005)$ in group B.No significant improvement observed at 6 months followup. Pressure symptoms had not improved at all in both the groups at both $3 \& 6$ months follow up. On comparing both the drugs the effect on HMB without dysmenorrhea, HMB with dysmenorrhea and pressure symptoms were found to be comparable with no statistically significant difference $(\mathrm{p}>0.005)$

Table 1: Socio Demographic profile of participants

\begin{tabular}{|c|c|c|}
\hline \multirow{2}{*}{ Variables } & \multicolumn{2}{|c|}{ Frequency (\%) } \\
\cline { 2 - 3 } & Group A (N=43) & Group B (N=44) \\
\hline Mean age \pm SD & $40.8 \pm 6.8$ & $41.2 \pm 7.0$ \\
\hline Residence & Frequency(\%) & Frequency(\%) \\
\hline Urban & $33(76.7 \%)$ & $40(90.9 \%)$ \\
\hline Rural & $10(23.3 \%)$ & $4(9.1 \%)$ \\
\hline Socio economic status & Frequency(\%) & Frequency(\%) \\
\hline Upper & $5(11.6 \%)$ & $4(9.1 \%)$ \\
\hline Middle & $28(65.1 \%)$ & $27(61.4 \%)$ \\
\hline Lower & $10(23.2 \%)$ & $13(29.5 \%)$ \\
\hline Marital status & Frequency(\%) & Frequency(\%) \\
\hline Unmarried & $5(11.6 \%)$ & $2(4.6 \%)$ \\
\hline Married & $38(88.4 \%)$ & $42(95.5 \%)$ \\
\hline Parity & Frequency (\%) & $3(6.8 \%)$ \\
\hline P0 & $5(11.62 \%)$ & $6(13.6 \%)$ \\
\hline P1 & $6(13.95 \%)$ & $7(15.9 \%)$ \\
\hline P2 & $8(18.60 \%)$ & $16(36.3 \%)$ \\
\hline P3 & $14(32.55 \%)$ & $12(27.2 \%)$ \\
\hline$>$ P3 & $10(23.25 \%)$ & Frequency $(\%)$ \\
\hline
\end{tabular}


Table 2: Symptomatology profile at baseline and response at 3 months and 6 months

\begin{tabular}{|c|c|c|c|c|c|}
\hline $\begin{array}{c}\text { Clinical } \\
\text { Features }\end{array}$ & $\begin{array}{c}\text { Time } \\
\text { period }\end{array}$ & $\begin{array}{l}\text { Group A (mifepristone) } \\
\text { Frequency }(\%) \text { (p-value) }\end{array}$ & $\begin{array}{l}\text { Group B(ormeloxifen) } \\
\text { Frequency (\%) (p-value) }\end{array}$ & $\begin{array}{l}\text { Total Patients } \\
\text { Frequency }(\%)\end{array}$ & $\begin{array}{l}\text { P Value (group } \\
\text { A vs group B) }\end{array}$ \\
\hline \multirow{3}{*}{$\begin{array}{l}\text { HMB without } \\
\text { dysmenorrhea }\end{array}$} & Baseline & $22(51.2 \%)$ & $20(45.5 \%)$ & $42(50 \%)$ & $\mathrm{P}=0.826$ \\
\hline & 3 months & $10(23.3 \%) ; \mathrm{P}<0.005$ & $11(25.0 \%) ; \mathrm{P}<0.005$ & & $\mathrm{P}=0.629$ \\
\hline & 6 months & $3(6.9 \%) ; \mathrm{P}<0.001$ & $3(6.8 \%) ; \mathrm{P}<0.001$ & & $\mathrm{P}=0.782$ \\
\hline \multirow{3}{*}{$\begin{array}{c}\text { HMB with } \\
\text { dysmenorrhea }\end{array}$} & Baseline & $11(25.6 \%)$ & $12(27.3 \%)$ & $23(27.3 \%)$ & $\mathrm{P}=0.086$ \\
\hline & 3 months & $4(9.3 \%) ; \mathrm{P}<0.005$ & $3(6.8 \%) ; \mathrm{P}<0.005$ & & $\mathrm{P}=0.829$ \\
\hline & 6 months & $4(9.3 \%) ; \mathrm{P}=0.072$ & $2(4.5 \%) ; \mathrm{P}=0.761$ & & $\mathrm{P}=0.761$ \\
\hline \multirow{3}{*}{$\begin{array}{l}\text { Pressure } \\
\text { symptoms }\end{array}$} & Baseline & $2(4.7 \%)$ & $1(2.3 \%)$ & $3(3.5 \%)$ & $\mathrm{P}=0.822$ \\
\hline & 3 months & $2(4.7 \%) ; \mathrm{P}=0.821$ & $1(2.3 \%) ; \mathrm{P}=0.732$ & & $\mathrm{P}=0.062$ \\
\hline & 6 months & $2(4.7 \%) ; \mathrm{P}=0.868$ & $1(2.3 \%) ; \mathrm{P}=0.788$ & & $\mathrm{P}=0.266$ \\
\hline
\end{tabular}

Fig. $1,2 \& 3$ : The baseline mean PBAC score was $246.65 \pm 9.14$ and $242.43 \pm 12.9$; Mean VAS Score- $7.5 \pm 1.4$ and 7.05 \pm 1.7 ; Mean ET- 7.48 \pm 1.4 and 7.84 \pm 1.6 in group A and group B respectively.At 3 months,significant reduction was noticed in mean PBAC score; $130.56 \pm 5.7(p<0.0001), 132.38 \pm 5.61(p<0.0001)$; mean VAS score $2.66 \pm 0.4(p<0.009), 2.5 \pm 0.6(p<0.0001)$ in group A and group B respectively.

At 6 months followup significant improvement continued in mean PBAC score; $65.23 \pm 4.08$ ( $\mathrm{p}<0.0001), 66.57 \pm 3.81$ $(\mathrm{p}<0.0001)$ in both group A and B respectively but mean VAS Score showed insignificant difference $(\mathrm{p}<0.216),(\mathrm{p}<0.312)$ in both the drugs. The efficacy of both the drugs in relation to mean PBAC Score \& VAS Score were comparable $(\mathrm{p}>0.001)$ Mean ET was reduced to $5.76 \pm 3.18(\mathrm{P}<0.0001)$ and $3.47 \pm 1.40(\mathrm{p}<0.0001)$ in group A at $3^{\text {rd }}$ and $6^{\text {th }}$ month followup.In contrast group B showed increase in mean ET; $7.87 \pm 1.7$ that was initially insignificant ( $\mathrm{P}$ value $=0.065)$ but became significant $9.41 \pm 0.87(\mathrm{p}<0.0001)$ at 6 month.

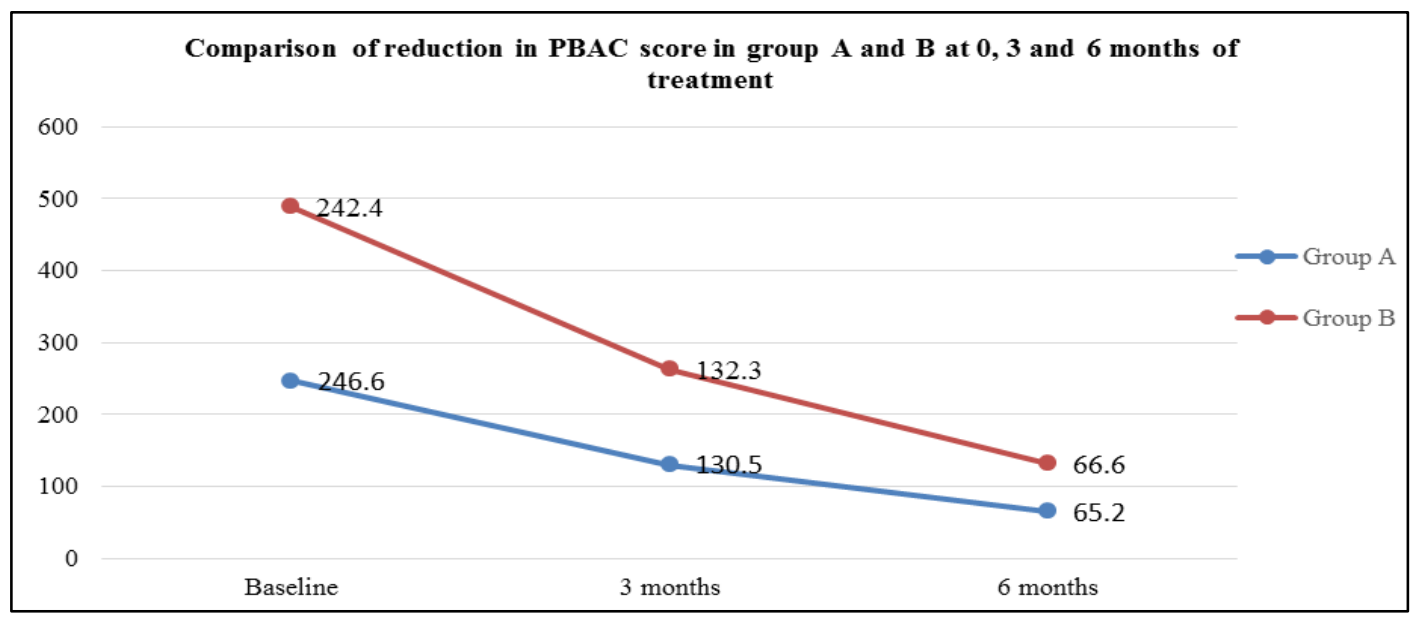

Fig. 1: Mean PBAC score at baseline, 3 months and 6 months of treatment

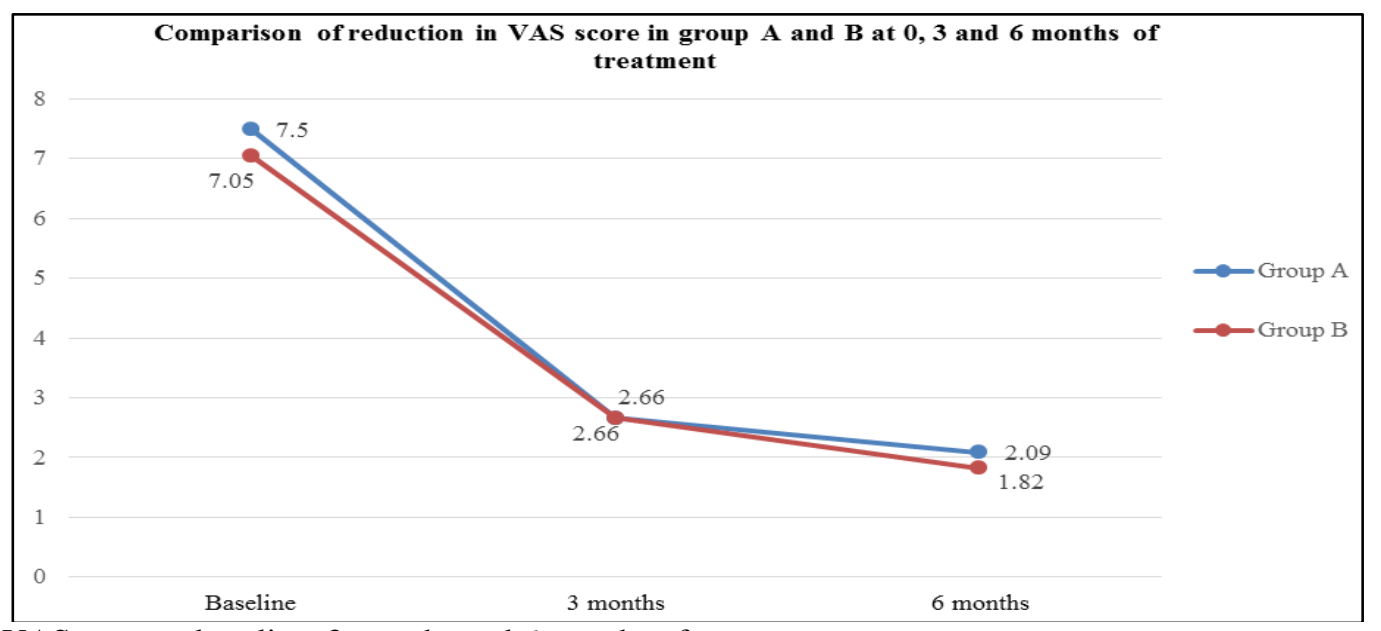

Fig. 2: Mean VAS score at baseline, 3 months and 6 months of treatment 


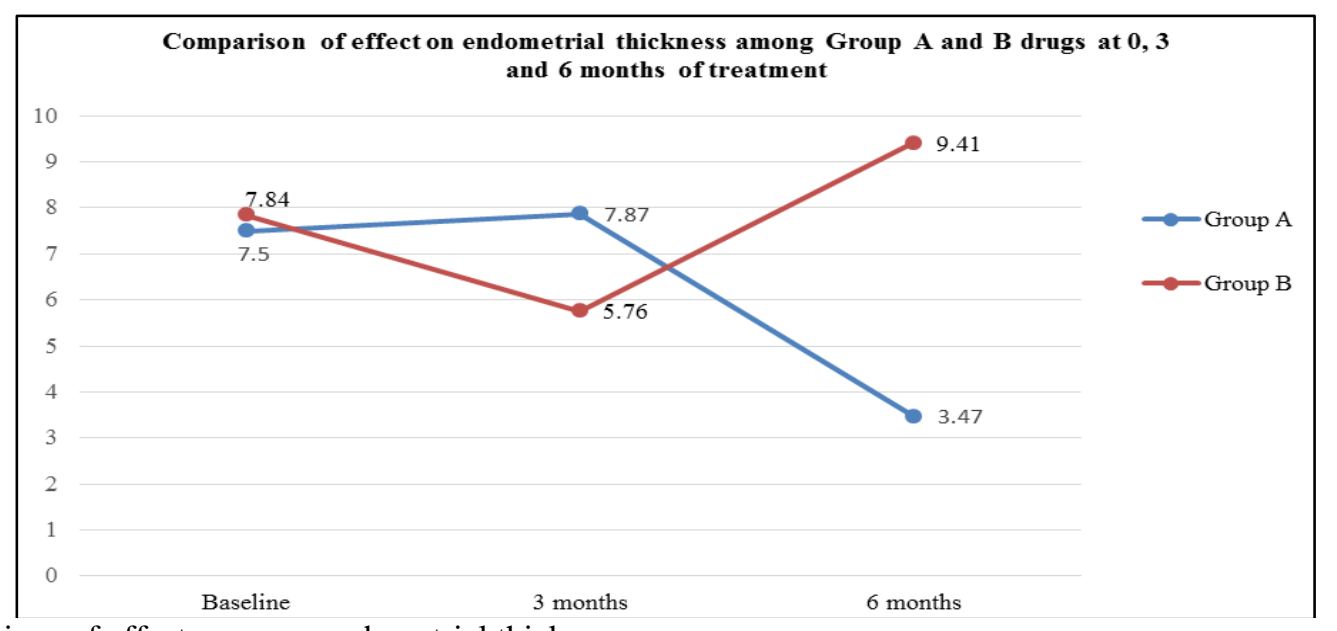

Fig. 3: Comparison of effect on mean endometrial thickness

Table 3: Baseline mean fibroid size along with Doppler flow Velocimetry were comparable in both the groups $(\mathrm{p}<0.312$; $\mathrm{p}<0.870,0.450)$.

In Group A significant reduction was found in size of fibroid at both 3 and 6 month; $4.0 \pm 2.4(\mathrm{p}<0.005), 3.0 \pm 2.1$ $(\mathrm{p}<0.001)$ respectively, along with significant improvement in PI and RI;0.88 $\pm 0.24(\mathrm{p}<0.044) ; 0.59 \pm 0.24(\mathrm{p}<0.043)$ and $0.97 \pm 0.19(\mathrm{p}<0.001) ; 0.65 \pm 0.19(\mathrm{p}<0.05)$ at 3 and 6 month respectively.

Group B showed no significant reduction in size of fibroid both at $3 \& 6$ month; $5.3 \pm 2.2(\mathrm{p}=0.214), 4.8 \pm 1.8(\mathrm{p}=0.624)$ but reduced vascularity with improvement in PI and RI values were noticed at 3month;0.90 $\pm 0.24(\mathrm{p}<0.006) ; 0.6 \pm 0.18$ $(\mathrm{P}<0.04)$ and 6 months; $0.98 \pm 0.17(\mathrm{p}<0.05) 0.68 \pm 0.14$ ( $\mathrm{p}<0.03)$ followup.

On comparing both the groups the fibroid size was significantly more reduced in Group A in comparison to Group B $(\mathrm{p}<0.005 ; \mathrm{p}<0.001)$ but improvement in vascularity were found to be comparable both at 3 \& 6 $\operatorname{month}(\mathrm{p}=0.845,0.764 ; \mathrm{p}=0.812,0.450)$

Table 4: No serious adverse effects were noted in both groups. The most worrisome side effect was infrequent menstruation, more commonly associated with ormeloxifen than mifepristone; $61 \%$ Vs. $55.8 \%$.

Table 3: Mean Fibroid size, Doppler velocimetry at baseline, 3 months and 6 months among the study population

\begin{tabular}{|c|c|c|c|}
\hline & $\begin{array}{c}\text { Group A } \\
\text { Mean } \pm \text { S.D (p-value) }\end{array}$ & $\begin{array}{c}\text { Group B } \\
\text { Mean } \pm \text { S.D }(\mathbf{p} \text { value) }\end{array}$ & $\begin{array}{c}\text { p Value(Group A } \\
\text { vs Group B) }\end{array}$ \\
\hline \multicolumn{4}{|c|}{ Fibroid Size } \\
\hline Baseline & $6.2 \pm 1.8$ & $5.8 \pm 2.0$ & 0.312 \\
\hline 3 months & $4.0 \pm 2.4 ; \mathrm{p}<0.005$ & $5.3 \pm 2.2 ; \mathrm{p}=0.214$ & $<0.005$ \\
\hline 6 months & $3.0 \pm 2.1 ; \mathrm{p}<0.001$ & $4.8 \pm 1.8 ; \mathrm{p}=0.624$ & $<0.001$ \\
\hline \multicolumn{4}{|c|}{ Doppler velocimetry } \\
\hline Baseline & $0.78 \pm 0.23$ & $0.77 \pm 0.18$ & 0.870 \\
\hline PI* & $0.50 \pm 0.23$ & $0.51 \pm 0.24$ & 0.450 \\
\hline RI $^{\#}$ & & $0.90 \pm 0.24 ; \mathrm{p}=0.006$ & 0.845 \\
\hline 3 months & $0.88 \pm 0.24 \mathrm{p}=0.044$ & $0.60 \pm 0.18 ; \mathrm{p}=0.04$ & 0.764 \\
\hline PI & \multicolumn{3}{|c|}{} \\
\hline RI & $0.59 \pm 0.24 ; \mathrm{p}=0.043$ & $0.98 \pm 0.17 ; \mathrm{p}<0.05$ & 0.812 \\
\hline 6 months & $0.97 \pm 0.19 ; \mathrm{p}<0.001$ & $0.68 \pm 0.14 ; \mathrm{p}<0.03$ & 0.450 \\
\hline PI & $0.65 \pm 0.19 ; \mathrm{p}<0.05$ & 0 & \\
\hline RI & &
\end{tabular}

*PI: Pulsatality index, ${ }^{\#}$ RI: resistivity index 
Table 3: Side effects due to the two drugs among the patients

\begin{tabular}{|c|c|c|c|}
\hline Side Effects & $\begin{array}{c}\text { Group A } \\
\text { Frequency (\%) }\end{array}$ & $\begin{array}{c}\text { Group B } \\
\text { Frequency (\%) }\end{array}$ & p value \\
\hline Nausea and vomiting & $3(7.0 \%)$ & $1(2.3 \%)$ & 0.462 \\
\hline Headache & $2(4.7 \%)$ & $1(2.3 \%)$ & 0.824 \\
\hline Abdominal pain & $5(11.7 \%)$ & $2(4.5 \%)$ & 0.628 \\
\hline Amenorrhea & $2(4.7 \%)$ & $3(6.8 \%)$ & 0.092 \\
\hline Infreqent menses & $24(55.8 \%)$ & $27(61.4 \%)$ & 0.088 \\
\hline
\end{tabular}

\section{Discussion}

Our study demonstrates that the self-reported prevalence of uterine fibroids was highest in fourth decade that is very similar and consistent with other studies like Anne Zimmermann et al; 2012 in Germany ${ }^{8}$ and H. Eisinger et al; 2009 in Meldrum ${ }^{9}$ who also found highest prevalance in the age groups ranging between $41-49$ years. ${ }^{10}$ Although the inverse association between myoma risk and parity is well known $^{5-7}$ the noncomparable findings of getting myomas in women with multiparity may be explained by strong social practice of mandatory marriage and early child bearing in the initial years of marriage only. So by the time myoma tends to grow in the uterus, the women already had pregnancy and child bearing. The most common presenting complaint has been documented to be HMB and dysmenorrhea ${ }^{30}$ as found in this study also.

Mifepristone caused reduction in the menstrual blood loss, fibroid size and vascularity by its antiprogestogenic effect thus rendering progesterone induced activities like increased VEGF $^{14,15}$ increased EGF, increased leiomyomatous cell proliferation.

Relief in dysmenorrhea is due to reduced production of prostaglandins,Vasopressin and endothelin induced spasmodic uterine contractions ${ }^{18,19}$ Significant improvement in dysmenorrhea was found in initial months that plateaued after 3 months depicts obvious pain relief from distressing pain visible on the VAS Scale that reduced to less, to be noticed in later months.

The same findings had been explained by Alka Kriplani et al, 2009, New Delhi ${ }^{16}$ and Vidushi Kulshrestha et al, 2013, New Delhi ${ }^{17}$ and DasguptaM, et al, 2016, in West Bengal. $^{20}$

Though mifepristone caused reduced menstrual blood loss, fibroid size and vascularity, the ET was increased both at $3 \& 6$ months as has also been shown by Dhananjay BS et al, 2013, Pondicherry ${ }^{26}$ (a significant increase in mean ET from $6.82 \pm 1.18$ to $9.92 \pm 2.72 ; \mathrm{p}<0.001)$. It blocks progesterone receptors which leads to unopposed action of estrogen on endometrium causing increased endometrial proliferation. ${ }^{13,14}$

Moreover, mifepristone has been found to increase in plasma ACTH leading to rise in plasma cortisol and adrenal androgen. The peripheral aromatization of adrenal androgen to estradiol causes further increase in estrogen levels causing endometrial proliferation. ${ }^{13-14}$

Ormeloxifen reduced Mean PBAC Score, VAS Score, Vascularity and Endometrial thickness by antagonizing induced proliferation of endometrium ${ }^{15}$ and fibroid itself and decreased production of VEGF, EGF.
Ormeloxifen primarily antagonizes estrogenic action of endometrium only and not on myoma, ${ }^{31}$ thus had no effect on size of fibroid.

Similar results were also explained by Dasgupta, M, et al,2016, in West Bengal Amenorrhea caused by both the drugs was counted as side effect rather we found it welcome by the patient to recover their anaemia and mental distress that was caused by HMB.The side effect profile included no major event, similar to the study conducted by Carbonell Esteve et al,2008 Cuba and Sachita Karmakar et al,2013 in Pune ${ }^{27,28}$

\section{Conclusion}

Treatment of uterine fibroids by mifepristone or ormeloxifen was associated with reduction in menstrual blood loss and pain with equal efficacy. It was found that mifepristone reduced the size of fibroid more effectively while ormeloxifen had significant effect on endometrial thickness. We concluded from the study that both these drugs can be used for treatment of symptomatic fibroids with negligible side effects but mifepristone should be preferred over ormeloxifen if considerable reduction in fibroid size is desired.

\section{Conflict of Interest: None.}

\section{References}

1. Kumar P, Malhotra N. Jeffcoate's principle of Gynecology. 7th ed. New Delhi: Jaypee Brothers Medical Publication (P) ltd; 2008.

2. Cook H, Ezzati M, Segars JH, McCarthy-Keith D. The impact of uterine leiomyomas on reproductive outcomes. Minerva Ginecologica. 2010. p. 225-36.

3. Donnez J, Jadoul P. What are the implications of myomas on fertility? A need for a debate, Hum Reprod 2002;17(6):142430 .

4. Cermik D, Arici A, Taylor HS. Coordinated regulation of HOX gene expression in myometrium and uterine leiomyoma. Fertil Steril 2002;78(5):979-84. Available from: http://www.ncbi.nlm.nih.gov/pubmed/12413981

5. Matsuo H, Maruo T, Samoto T. Increased expression of Bcl-2 protein in human uterine leiomyoma and its up-regulation by progesterone. J Clin Endocrinol Metab 1997;82(1):293-9.

6. Maruo T, Matsuo H, Shimomura Y, Kurachi O, Gao Z, Nakago S, et al. Effects of progesterone on growth factor expression in human uterine leiomyoma. Steroids 2003;68(1013):817-24.

7. Chegini N, Ma C, Tang XM, Williams RS. Effects of GnRH analogues, 'add-back' steroid therapy, antiestrogen and antiprogestins on leiomyoma and myometrial smooth muscle cell growth and transforming growth factor- $\beta$ expression. $\mathrm{Mol}$ 
Hum Reprod 2002;8(12):1071-8.

8. Zimmermann A, Bernuit D, Gerlinger C, Schaefers M, Geppert K. Prevalence, symptoms and management of uterine fibroids: an international internet-based survey of 21,746 women. BMC Womens Health 2012;12:6

9. Eisinger SH, Fiscella J, Bonfiglio T, Meldrum S, Fiscella K. Open-label study of ultra low-dose mifepristone for the treatment of uterine leiomyomata. Eur J Obstet Gynecol Reprod Biol 2009;146:215-8.

10. Eisinger SH, Meldrum S, Fiscella K, Le Roux HD, Guzick DS. Low-dose mifepristone for uterine leiomyomata. Obstet Gynecol 2003;101(2):243-50.

11. Khyade RL, More RM. Fibromyoma of the uterus and its surgical management. Int J Reprod Contraception Obstet Gynecol 2017;6(8):3637-40.

12. Shimomura Y, Matsuo H, Samoto T, Maruo T. Up-regulation by progesterone of proliferating cell nuclear antigen and epidermal growth factor expression in human uterine leiomyoma. J Clin Endocrinol Metab 1998;83(6):2192-8. http://www.ncbi.nlm.nih.gov/entrez/query.fcgi?cmd=Retrieve $\& \mathrm{db}=$ PubMed \&dopt=Citation\&list_uids $=9626159$

13. Lundström V, Gréen K, Wiqvist N. Prostaglandins, indomethacin and dysmenorrhea. Prostaglandins 1976;11(5):893-904.

14. ÅKerlund M, Andersson K -E., Ingemarsson I. Effects of Terbutaline on Myometrial activity, uterine blood flow, and lower abdominal pain in women with primary dysmenorrhoea. BJOG 1976;83(9):673-8.

15. Makker A, Tandon I, Goel MM, Singh M, Singh MM. Effect of ormeloxifene, a selective estrogen receptor modulator, on biomarkers of endometrial receptivity and pinopode development and its relation to fertility and infertility in Indian subjects. Fertil Steril 2009;91(6):2298-307.

16. Efficacy and safety of ormeloxifene in management of menorrhagia: A pilot study Alka Kriplani, Vidushi Kulshrestha, Nutan Agarwal. J Obstet Gynaecol Res 2009;35(4):746-52.

17. Vidushi Kulshrestha, Alka Kriplani, Nutan Agarwal, Neetu Sareen, Pradeep Garg, Smriti Hari, , and Jyoti Thulkar Low dose mifepristone in medical management of uterine leiomyoma - An experience from a tertiary care hospital from north India. Indian J Med Res 2013:137(6):1154-62.

18. Shelly W, Draper MW, Krishnan V, Wong M, Jaffe RB. Selective estrogen receptor modulators: an update on recent clinical findings. Obstet Gynecol Surv 2008;63(3):163-81. Available from: http://www.ncbi.nlm.nih.gov/pubmed/18279543

19. Narvekar N, Critchley HOD, Cheng L, Baird DT. Mifepristone-induced amenorrhoea is associated with an increase in microvessel density and glucocorticoid receptor and a decrease in stromal vascular endothelial growth factor. Hum Reprod 2006;21(9):2312-8.

20. Dasgupta M, Karlo B, Biswas R, Bag T, Dutta S. Evaluation of the SERM Ormeloxifene in the Treatment of Uterine Fibroid in the Reproductive Age Group. J Syndromes 2016;3(2):5. ISSN: 2380-6036 Gynecol Scand Suppl 150

21. Spitz IM. Mifepristone: where do we come from and where are we going? Clinical development over a quarter of a century. Contracept 2010;82(5):442-52.

22. Paech K, Webb P, Kuiper GGJM, Nilsson S, Gustafsson JA, Kushner PJ et al. Differential ligand activation of estrogen receptors ER $\alpha$ and ERr $\beta$ at AP1 sites. Sci 1997;80;277(5331):1508-10.

23. Wong JYY, Gold EB, Johnson WO, Lee JS. Circulating sex hormones and risk of uterine fibroids: Study of women's health across the nation (swan). J Clin Endocrinol Metab 2016;101(1):123-30.

24. Kurachi O, Matsuo H, Samoto T, Maruo T. Tumor necrosis factor-alpha expression in human uterine leiomyoma and its down-regulation by progesterone. J Clin Endocrinol Metab 2001;86(5):2275-80. Available from: http://www.ncbi.nlm.nih.gov/pubmed/11344239

25. Ross RK, Pike MC, Vessey MP, Bull D, Yeates D, Casagrande JT. Risk factors for uterine fibroids: reduced risk associated with oral contraceptives. Br Med J Clin Res Ed 1986;293(6543):359-62. Available from: http://www.pubmedcentral.nih.gov/articlerender.fcgi?artid=13 41047\&tool=pmcentrez\&rendertype $=$ abstract

26. BS Dhananjay, Nanda SK. The Role of Sevista in the Management of Dysfunctional Uterine Bleeding. J Clin Diagn Res 2013;7(1):132-4. doi:10.7860/JCDR/2012/4794.2687.

27. Carbonell Esteve JL, Acosta R, Heredia B, Pérez Y, Castañeda MC, Hernández AV. Mifepristone for the treatment of uterine leiomyomas: a randomized controlled trial. Obstet Gynecol 2008;112:1029-1036.

28. Sanchita Karmakar, Hemant Deshpande, Ormeloxifene. A new treatment modality in Dysfunctional Uterine Bleeding: efficacy and safety, Indian J Obstet Gynecol Res 2016;3(3):225-8.

29. Greb RR, Bukowski R, Hsiu JG, Williams RF, Hodgen GD, Goodman AL. Vascular Endothelial Growth Factor (VEGF) in Primate Endometrium: Immunohistochemical Patterns during the Cycle and after Chronic RU 486 Treatment in Cynomolgus Monkeys. Ann N Y Acad Sci 1995;761(1):376-82

30. Etiology, symptomatology, and diagnosis of uterine myomas William H. Parker,_Department of Obstetrics and Gynecology, UCLA School of Medicine, Los Angeles, California

31. Singh HO, Singh A, Dhole TN, Nain S. Effect of ormeloxifene for management of dysfunctional uterine bleeding. Biochem Physiol 2015;4:174.

How to cite this article: Singh M, Chourasia A, Singh S, Sachan N, Comparison of ormeloxifen and mifepristone in management of leiomyoma uterus. Indian J Obstet Gynecol Res 2019;6(2):202-207. 